\title{
THE CONSTRUCTION OF MODERNITY IN PRE-INDEPENDENT INDONESIA AND ITS ENSUING MANIFESTATION IN CRITICAL DISCOURSE AND LITERARY THEORY
}

\author{
Paulus Sarwoto \\ Universitas Sanata Dharma \\ sar@usd.ac.id
}

\begin{abstract}
This article traces the development of what may be called Indonesian critical discourse particularly related to the position of "West" and "East" from the colonial period to the New Order era. The development of this discourse and its manifestation in Indonesian literary theory began with a postcolonial debate on the construction of Indonesian modernity, i.e., toward which center it is going to be oriented. The tension between Western-centric discourse, on the one hand, and traditional orientation, on the other, characterized the earliest intellectual debate in the 1930s. This argument took a different contour in the 196os when the tension turned out to be between social realism and liberal humanism. The banning of leftist ideology and teaching after 1965 gave way to the unchallenged dominance of the traditional humanist outlook in the literary-critical scene. The paper argues that the present hegemony of traditional humanist approach in Indonesian consciousness is rooted in its distinctive development in these few decades.
\end{abstract}

\section{Keywords}

culture polemic, Lekra, Manikebu, social realism, humanism, postcolonial

\section{About the Author}

Paulus Sarwoto is the Chair of the English Language Studies Graduate Program of Universitas Sanata Dharma, Yogyakarta, Indonesia. He holds a Ph.D. in Comparative Literature and Cultural Studies from Monash University. His research interests include postcolonial theory, cultural studies, and comparative literature. He is currently working on his book project entitled The Javanese in Transition: A Postcolonial Study of the Priyayi Class in the Works of Indonesian Author Umar Kayam. 
The discourse on the construction of Indonesian modernity cannot be separated from the problematical relation between "Eastern" and "Western" ideas in Indonesian critical debates that date back to 1934 in the so-called polemik kebudayaan (culture polemic), about the hemisphere toward which Indonesian culture should be oriented. In subsequent years, the East and West antagonism was also reflected in another cultural debate involving Lekra (the People's Culture Institute, affiliated with the Indonesian Communist Party, or the PKI) and Manikebu (Cultural Manifesto) in the 1960s and finally in the 1980 in the public polemic of sastra kontekstual (contextual literature). The sastra kontekstual debate and the efforts to formulate Indonesian poetics in the following years contained the residual polemic of the 1930 s that were re-formulated in response to the contemporary context. Although the thinkers of each period never explicitly referred to the previous debate, this paper will show that the ensuing argument in the 1960 s and the 1980 os cannot be separated from the first intellectual debates that took place in the 1930 .

\section{POLEMIK KEBUDAYAAN: WEST VERSUS EAST}

Polemik kebudayaan (culture polemic) refers to the public argument among early Indonesian intellectuals about the future of Indonesian culture that took place in the literary journal Pujangga Baru. The articles on the subject were published in PolemikKebudayaan (1948). The debate was triggered by Soetan Takdir Alisjahbana's article "Мепијu Masyarakat dan Kebudayaan Baru" (Towards a New Community and Culture) published in Pujangga Baru on 2 August 1935. Although Pujangga Baru was a literary periodical, the debate was laden with political nuances since the atmosphere of the time was becoming politically charged against the backdrop of rising demands from Indonesian nationalists for self-government, on the one hand, and sterner colonial rule, on the other. ${ }^{1}$ In this article, Alisjahbana emphasizes the importance for Indonesians to separate the past, which he calls pre-Indonesia, from the present Indonesia. He criticizes the efforts to relate the formation of Indonesia in the 1930 s with the local heroes fighting Dutch colonialism in the $19^{\text {th }}$ century, such as Diponegoro, Tuanku Imam Bonjol, and Teungku Umar. He argues that those figures fought for their local territories' independence and had no idea of an Indonesia being comprised of very diverse regions. There is no guarantee, Alisjahbana continues, that if they had had a chance, they would not have invaded other regions themselves because of their parochialism. As he says:

Diponegoro berjuang bagi Tanah Jawa itu pun agaknya tiada dapat kita katakan bagi seluruh Tanah Jawa. Tuanku Imam Bonjol bagi Minangkabau, Teungku Umar bagi Aceh. Siapa yang dapat menjamin sekarang ini, bahwa baik Diponegoro, baik Tuanku 
Imam Bonjol, ataupun Teungku Umar tidak akan melabrak bahagian kepulauan ini yang lain sekiranya mereka mendapat kesempatan dahulu?

Diponegoro fought for part of Java and not all of Java. Tuanku Imam Bonjol did the same for Minangkabau, and Teungku Umar for Aceh. Who can guarantee now that had they had a chance to invade other regions they would not have done so? (Mihardja 14)

Alisjahbana concludes that Indonesia is a twentieth century invention and so trying to return to the past in formulating the present Indonesia is a big mistake. To support his argument, Alisjahbana critically assesses the gigantic stone temple, Borobudur, a monument that has often been glorified as grand achievement of the past, as an evidence of Javanese domestic colonialism in the form of the imposition of slavery by minority elites and the poverty that this entailed (Teeuw 37).

Alisjahbana does not find the past enlightening and in this respect his argument is not unlike a prominent thinker of early postcolonial theory, Frantz Fanon, who also criticizes past romantization by arguing that the colonizer will not be embarrassed simply by being shown some artifacts indicating that the colonized people were once a high-achieving civilization. Fanon also asserts that returning to the past in order to find some comfort from colonial degradation is utopian and unrealistic, and he suspects that this unrealistic drive is motivated by a psychological need or a psychic defence mechanism:

Perhaps this passionate research and this anger are kept up or at least directed by the secret hope of discovering beyond the misery of today, beyond self-contempt, resignation and abjuration, some very beautiful and splendid era whose existence rehabilitates us both in regard to ourselves and in regard to others. (Fanon 37)

Instead of returning to the past, Alisjahbana proposes the West as the point of reference to build Indonesia. The idea of Indonesia, Alisjahbana adds, was espoused by Indonesians educated in the Netherlands. On their return to Indonesia, they could formulate the concept of a modern independent state because of their Western education. The West, in his opinion, has helped awaken the Indonesians from slumber. Western values, Alisjahbana states, will be able to contribute to the development of Indonesia into a better state. Alisjahbana was not directing his comments in a way that links to contemporary postcolonial literary critical debate; however, interestingly, his article indicates how at that point in Indonesia's history the construction of the concept of Indonesia was not only already polarized by the existence of a colonial debate-inevitably one involving the value of modernity for an emerging nation-but was also already engaging with the complex relationship between a state marked by colonial boundaries and its constituent parts. It is noteworthy that both points deeply affected the distinctive nature of the Indonesian 
postcolonial situation, its reflection in literary production, and the kinds of theory that are appropriate to this literature.

While Alisjahbana stresses the importance of leaving behind pre-Indonesia concepts and turning to the West, Sanusi Pane, responding to Alisjahbana in 1935, argues for the importance of combining West and East in the Indonesia project. What Pane means by "East" is the mysticism, compassion, and collectivism that he assumes to have resided in the character of Indonesians as part of the East. He posits that these Eastern characters are contradictory to Western values, which Pane describes as dominated by materialism, intellectualism, and individualism. Further, Pane symbolises the West as Faust and the East as Arjuna, a wayang figure. Faust is a character who sacrifices his soul in order to master the material world. Arjuna, on the other hand, is described as a character who prioritizes his soul's well-being to the point of neglecting his physical condition. As he says:

Timur mementingkan rohani, sehingga lupa akan jasmani. Akalnya dipakainya mencari jalan mempersatukan dirinya dengan alam. Ia bersifat Arjuna yang bertapa di Indrakila.

The East prioritizes the spiritual so that he forgets the body. He uses his mind to find a way to unite with nature. He has Arjuna's character with his ascetic life in the Indrakila Mountain. (Mihardja 25)

In short, Pane thinks that the West and the East have their own negative and positive characteristics and it is the task of Indonesians to navigate the landscape in order not to get lost in one of these two extremes.

The role of Indonesian as a national language was ambivalent at this stage. Quite different from the British or French colonization, the Dutch never enforced the Dutch language to the peoples of the East Indies. Only a minority of the elite did speak Dutch, while the majority of Indonesians spoke in their various vernacular languages. In response to the need for communication among these different tribes the people developed a lingua franca out of Malay which has been called Bahasa Indonesia since 1928.

The constitution of Indonesian as the national language has contributed to the complexity of the formation of literature in the pre-independent East Indies, especially because it is a language that is not rooted in any of the Indies' vernacular languages. When literature had to develop in this national language, most vernacular poets initially faced a language barrier because they had to express what they had experienced in their "vernacular" life in a language that is not yet-in Pram's language_-"the language of family" (qtd. in Day and Foulcher 201). 
Nevertheless, some works seemed undaunted by this new language medium and were able to use it with ease as evidenced by such works as Salah Asuhan, Siti Nurbaya, and some Malay works adapted from Western narratives such as The Count of Monte Cristo, Robinson Crusoe, and Sherlock Holmes. However, many other works struggled to accommodate this new language medium of writing and negotiated with it in order to capture the local linguistic landscape in the language of literature.

Foulcher refers to this discussion as: "the first extended attempt by Indonesian nationalist intellectuals to come to grips with "Indonesia" as a cultural, as well as a political, entity" (Pujangga Baru 1). This early critical discourse on Indonesian culture in the pre-independence period involved strong essentialist arguments of what constitutes West and East. This essentialist discourse is reminiscent of the issue that Said also critiques in Orientalism (1978) because it tends to be manipulated by the reigning power. After independence, the arguments took a different turn when different ideologies and political parties began to compete for a national leadership. A number of cultural thinkers were affiliated with political parties, and this polarized situation heated up the debates and filled the rhetoric with political interests and nuances.

\section{LIBERAL HUMANISM VERSUS SOCIAL REALISM}

Indonesia proclaimed its independence from the Dutch on 17 August 1945 and gained full sovereignty on 31 December 1949. Five years after Indonesia proclaimed its independence, on 18 February 1950, Asrul Sani and his colleagues published a manifesto entitled "Surat Kepercayaan" (Statement of Beliefs) in Gelanggang, "the literary section of the weekly magazine Siasat" (Nordholt 6). This publication has been applauded as the evidence of Indonesians' early determination to establish an internationalist stance by many, such as Henk Schulte Nordholt and Taufik Abdullah. Nordholt translates the opening of the statement as follows:

We are the legitimate inheritors of the culture of the whole world, [...] and we shall transmit this culture in our own way. We come from the ordinary people and for us the people are a mixture of everything from where a new and healthy world would be born. (6)

Kami adalah ahli waris jang sah dari kebudajaan dunia dan kebudajaan ini kami teruskan dengan tjara kami sendiri. Kami lahir dari kalangan orang-banjak dan pengertian rakjat bagi kami adalah kumpulan tjampur-baur dari mana dunia-dunia baru jang sehat dapat dilahirkan. (Kratz 182) 
Nordholt sees this statement as "the launch of a new outward-looking national identity, expressing optimism and self-confidence" (6). He therefore supports Taufik Abdullah's interpretation of the statement as expressing the awareness that:

the boundaries and rootedness of culture [are] irrelevant. Indonesian culture was no longer localized and materialized in ancient objects, because 'Indonesianess (keIndonesia-an) does not rest in our brown skins and cheek bones but rather in the expression of our hearts and minds.' (6)

Indeed, this statement may be said to reflect the eagerness of a new post-independent state to be a part of the world culture. The claim that they are the true heirs of world culture means that Indonesians too possess the right to claim the world culture. Despite Nordholt and Abdullah's affirmative and positive endorsement, however, this statement can be read as an indication of a major difficulty plaguing a postcolonial state's cultural expectations. As such, this publication may be viewed as suggestive of another curious theme of Indonesian postcolonial identity which had been debated upon in culture polemic. The opening of the statement asserts, "Kami adalah ahli waris yang sah dari kebudayaan dunia dan kebudayaan ini kami teruskan dengan cara kami sendiri" (We are the true heirs of world culture and we must perpetuate this culture in our own way" [Foulcher, Social Commitment in Literature and the Arts 3]). The blunder occurs in not realizing that the so-called "world culture" of the time was a Western construct that had relegated the rest of the world to the periphery. Given the fact that the Western construct of culture has given birth to worldwide colonialism, the Gelanggang's Statement of Beliefs sounds ironic. The history of colonialism had put the Indonesians on the losing side. Claiming the culture that gave birth to a system by which they had been oppressed as their own is certainly not enlightening. The Gelanggang statement is true insofar as Indonesians inherited the "oppression" signified by the current notion of world culture. The determination to perpetuate the world culture "in our own way" leads to further ironies since this can be interpreted as the commitment to perpetuate the culture of colonialism in the new state.

Lekra can be said to have opposed the stance of "Surat Kepercayaan." Established on 17 August 1950, Lekra aimed to ground culture, including literary production, on the social context, thus opposing the spirit of "Surat Kepercayaan" that assumes culture to be free from boundaries and rootedness. Lekra's doctrines could be summed up in two formulations: "seni untuk rakyat" (art for the people) and "politik adalah panglima" (politics is 'the Commander-in-Chief') (Yuliantri and Dahlan 16). With these doctrines, Lekra stipulated that cultural productions had to be based on the social reality of the oppressed and ought to support the revolutionary spirit of the time. Lekra's supporters believed that there was no place for a liberal humanist artist in times of revolution. These ideas were, of course, not 
reflective of the ordinary Indonesian's thinking but were imported from Russia and held by other communist literary intellectuals from the first half of the twentieth century.

Foulcher argues that there was actually a series of statements from Lekra over the 15 years of its existence which indicates a concern over the problematical relation between the artist and its society and shows that there was some factions within Lekra that did not view the relation between the base and superstructure in such simplistic terms as suggested by its most obvious doctrinal versions (7). However, this did not seem to be the majority view of Lekra. Kayam's Gestapu stories, for example, did not take into account Lekra's complex view on this issue and tended to describe Lekra's more totalitarian and simplistic view of literary production.

Responding to Lekra's increasingly aggressive stance, in September 1963 a group of poets and artists signed a manifesto called Manifes Kebudayaan (Cultural Manifesto) published in the literary magazine Sastra. This marked a renewed interest in the earlier liberal humanist thinking that emphasizes literature as an aesthetic, rather than social, product. The first two paragraphs of the statements state:

We, Indonesian creative artists and intellectuals, issue this Cultural Manifesto as a way of promulgating our basic position, ideals and understanding of the politics of a national culture.

We believe that culture represents the struggle to perfect the conditions of human existence. We do not privilege one sector of cultural activity over another. Each sector, depending on its own characteristics, works with every other sector in the struggle to achieve that culture (Mohamad 1).

Goenawan Mohamad, one of the signatories, recalled that they were fed up with the political atmosphere of the time and therefore: "the document was a strategy for creating more room for independent artistic expression-free from the political pressure and 'revolutionary' rituals that characterised the early 196os" (3). This insistence on personal and independent artistic expression characteristic of liberal humanism was seen by Lekra as a stance against the social realism that they advocated. Although both liberal humanism and social realism are derived from the West, those siding with Lekra considered social realism more appropriate to the Indonesian context and the Cultural Manifesto supporters were accused of supporting Western neocolonialism because of their allegedly neglect of the people's suffering in their literary works. ${ }^{2}$

The political elites in this period sided with Lekra with its revolutionary zeal. After a series of attacks from Lekra, the Cultural Manifesto was finally banned by 
President Soekarno for its allegedly anti-revolutionary spirit. This event was retold succinctly by Goenawan Mohamad:

It soon became obvious that the Manifesto, whatever our reason for composing and promulgating it, was considered as a challenge and an invitation to attack us. Between September 1963 and 8 May 1964, a series of bitter campaigns, often unjust but clearly systematic in nature, was launched, particularly by people having connections with the Nationalist and the Communist Parties. For seven months the Cultural Manifesto was criticised by various public statements, speeches and writers until it was finally banned.

(2)

However, soon after the failed coup d'état by some of elements of the Communist Party in October 1965 when the New Order regime came to power, Lekra and its proponents were banished from Indonesia's cultural institutions for approximately 33 years. With the total banishment of the Communist Party and all organizations affiliated with it-Lekra included-the liberal humanist stream of thought has since dominated the Indonesian literary scene. Liberal humanism manifested both in literary production and criticism in all its apolitical and universal themes and "disinterested" and "objective" stance. The focus of the writing began to revolve around the nature of the universality of humanity and the assumed "pure aesthetic" criteria in judging the value of literary works. Anything political was deemed not objective, and this was supported by the political regime of the New Order under president Suharto, already suspicious of any political motive behind any critical art production. In such an atmosphere, the dramatic works of WS Rendra, such as Perjuangan Suku Naga, Mastodon dan Burung Kondor, and Panembahan Reso are quite exceptional, and their productions landed him in jail under the New Order. It is interesting to note that the Suharto's New Order regime apparently deemed liberal humanism to be an ideological ally in the perpetuation of its dictatorship.

\section{SASTRA KONTEKSTUAL}

The sastra kontekstual (contextual literature) debate of the 1980 os was an attempt to move beyond liberal humanism and to consciously place Indonesian literature once again within a fully Indonesian context. The term was coined by Ariel Heryanto at a seminar in Solo, Central Java in October 1984 (4). Arief Budiman, a signatory of the Cultural Manifesto and a holder of a Ph.D. in sociology from Harvard, popularized the term and the arguments of sastra kontekstual through seminars and newspaper articles. Arief Budiman encouraged literary value judgment which did not have to be compliant with the hegemonic liberal humanist criteria. $\mathrm{He}$ 
advocated a literary reading that combined aesthetics, sociology, economics, and politics, especially in their relation to the local context (350).

The arguments turned out to be very slippery because the concept of sastra kontekstual itself was unclear from the verybeginning and invited counterarguments from many cultural thinkers, including Umar Kayam who argued that Indonesian literature was always contextual (236). Ariel Heryanto himself admitted that sastra kontekstual did not have a rigorous definition (19). Indeed, the understanding of sastra kontekstual becomes sharper as it develops and receives critiques from different perspectives. ${ }^{3}$ Several main concepts, however, can be outlined as follows. First of all, it implies a criticism directed against what might be thought of as a "liberal humanist" in the orientation of literary production and criticism-which the proponents of sastra kontekstual call "universal literature" - that thrived during the New Order. The domination of liberal humanism in Indonesian literature after the demise of social realism since the second half of the 1960 s was considered by the proponents of sastra kontekstual as unhealthy. Heryanto states:

Berbeda dari masa-masa sebelumnya, pada masa ini kesusastraan (untuk praktisnya, kita singkat saja:) "universal" ini mencapai zaman emasnya. Kesusastraan ini berjaya secara mapan, hampir-hampir tanpa saingan dan tandingan. Hal ini yang oleh Arief Budiman dipandang sebagai keadaan yang tidak sehat.

Unlike before, universal literature has now reached its golden age. This kind of literature thrives almost without challenge. This condition is not healthy, as Arief Budiman argues. (5-6)

This unhealthy situation, they argued, had given birth to literature that is monotonous, uniform, and Westernized (kebarat-baratan).

Secondly sastra kontekstual criticized the liberal humanist literary establishment that has become some kind of Indonesian literary Supreme Court. If new literary works were to be accepted as a quality of Indonesian literary works from the "periphery," they needed to seek the approval of important figures from the literary establishment who held key positions, and who mostly lived in Jakarta, Indonesia's "center." The universal humanist literary critics in charge of literary columns in the mass media had become an important factor in determining the quality of new works. This situation might also explain why works considered having good literary qualities have always been published in Jakarta.

This invitation to revisit the relation between literature and politics might have reminded some survivors from Lekra of their manifesto advocating "politics as 'the Commander-in-Chief."' However, Budiman and Heryanto did not advocate 
that doctrine at all. Rather they re-addressed the problematic relation between author and his social context that had also been discussed by a few number of Lekra writers in the early 1960 . They argued that by orienting the standard of good literature toward universal humanism, they might have neglected local problems more relevant to the Indonesian peoples. One obvious result of such an outlook, they argued, was an inferiority complex plaguing Indonesian writers for not being able to compete for international prizes and consequently desperate efforts to adopt Western literature in the hope of securing one.

Budiman's suggestion about the need for a new literary approach is important. Although schools of literary theory such as Structuralism, Post-structuralism, Deconstruction, Postmodernism, Feminism, and Postcolonialism have been much discussed in the West, most Indonesians theorists still hold to what Foulcher says is "the conception of the writer as individual creative personality, whose works, correctly interpreted in the light of 'Indonesian cultural values', speak to the universal human spirit" (12). The proposition of sastra kontekstual by Budiman and Heryanto can be said to be a reminder that the domination of a universalist school of criticism and literary style might have made critics and writers oblivious to the ideological nature of representation and criticism. Budiman and Heryanto emphasize the importance of rethinking the ways in which both literature and criticism need to have a local distinctiveness.

The efforts to formulate Indonesian theory continued into the 1980 os when some critics such as Subagio Sastrowardojo questioned the applicability of Western theory to criticize Indonesian literature and encouraged the formulation of what they considered to constitute "Indonesian poetics." The idea of inventing an Indonesian poetics was driven by the belief that value systems are not universal; since literary theory and criticism are constructed within certain value systems, their application to works across different value systems is questionable. In response to the application of Western theories, Rachmad Djoko Pradopo, in his dissertation, reports:

Oleh karena itu, timbullah berbagai reaksi atas penggunaan teori Barat itu, terutama pada tahun 1980-an. Reaksi pertama timbul pada awal tahun 1980an dengan "diskusidiskusi Sanggar Bambu" Yogyakarta yang berusaha mengarahkan terciptanya poetika (ilmu sastra) yang khas Indonesia. Reaksi kedua dicetuskan oleh Subagio Sastrowardojo (1984) dalam makalah kritik sastra pada temu sastrawan dan kritikus sastra di Jakarta (DKJ). Tulisan-tulisan Subagio Sastrowardojo yang mereaksi teori-teori sastra dari Barat itu menimbulkan usaha lebih luas untuk membentuk poetika yang khas Indonesia.

There were some responses on the use of Western theory, especially in the 1980 os. The first response was from the Bamboo Group in Yogyakarta by holding discussions in 
the early 1980 os in order to formulate Indonesian poetics. The second response was by Subagio Sastrowardojo (1984) through his article presented in a poets and critics forum at the Jakarta Arts Council. Subagio Sarstrowardojo's articles, responding to the use of Western theory, stimulated further efforts to formulate Indonesian poetics. (691)

These efforts to formulate an Indonesian poetics can be seen as Indonesians' efforts to fathom the degree of cultural boundedness and how far it undermines theory's application to literatures written in different cultures. One of the most notable efforts came at a seminar in 1988 whose proceedings were published in a book entitled Menjelang Teori dan Kritik Susastra Indonesia yang Relevan (In Search of Relevant Indonesian Literary Theory and Criticism).

Although the seminar could not formulate an Indonesian poetics, there are two points worth noting. First, the participants urged that the search for Indonesian theory should not be based on the inability to understand or keep up with the development of theory in the West. Second, while noting the importance of taking into account of local contents, it would be impossible to isolate theory from global conversations.

The downfall of the New Order in 1998 marks the new phase for freedom of expressions, including those in literary works. Two new prominent and yet contradictory trajectories have developed since then: the turn toward sexuality/sensuality and Islamic identity politics in novel writing. The demise of the authoritarian regime has meant more freedom which has resulted in the production of narratives with sexual explicitness, on the one hand, and the return toward Islamic identity politics, on the other. These paradoxical responses indicate different attitudes toward modernity. Modernity is perceived by some writers as an opening gate to secularization manifested in stories exploring sexuality and sensuality; for others, modernity and secularization are seen as a threat to religious identity; hence, the emergence of novels with strong Islamic flavor.

\section{CONCLUSION}

It may be true that some theories formulated in the West are not always suitable as theoretical tools for analyzing Indonesian literature, typically because such theories refer to and are shaped by literary works whose characteristics are probably absent in Indonesian literature. However, this proposition is not truer than the claim that no one single theory is applicable for all literary works. In a way, the construction of Indonesian modernity that has been revisited by the subsequent arguments marked by the zeal to break away from Western theory 
and formulate what is distinctively Indonesian symbolizes a postcolonial gesture for self-reliance. Within the present borderless world, this postcolonial academic exploration cannot be carried out while neglecting the global dialogues on theory. Otherwise, the scholarship developed would be too monolithic and often lead to replications of what have turned out to be outdated issues in global conversation. Indonesian discourse on modernity has a distinctive trajectory, and it is the discourse emanating from this trajectory that shall contribute to and help situate the discourse within the existing academic conversation.

The critical debate on contextual literature in the 1980s trying to return texts to what Edward Said calls textual worldliness, has not stimulated critical argument even after the downfall of the New Order in 1998, probably due to the Indonesians' reluctance about its Marxist undertone. This paradigm that was developed by, among others, the Cultural Materialists, should have been able to offer an alternative to the predominantly traditional humanist outlook of Indonesian critics. While this approach is mostly still terra incognita for Indonesian critics, it may be high time for this approach to unleash its critical capacity to interrogate the complicity of text, society, and the dominant power in maintaining the status quo. The search for Indonesian modernity has to be equipped with a critical scrutiny, such as found in Cultural Materialism, in assessing what Habermas calls the project of modernism since it often justifies marginalization in the name of progress. The emergence of contradictory narratives in response to modernity after the downfall of the New Order mentioned above demands an analysis combining the sharpness of Critical Theory and understanding the dynamic of local politics. In particular, it has shown the bifurcation in the history of literary criticism despite efforts to dictate a singular modernity in the practice of critical evaluation. 


\section{Notes}

1. Several political incidents around the period included the re-arrest of Soekarno in 1933, the Soetardjo petition asking for self-government, and the enforcement of the Restrictions on Rights of Assembly in 1934 by the Dutch government (Foulcher, Pujangga Baru 21).

2. H.B. Jassin, another signatory, had already pinpointed this loophole when in 1948 he criticized the term "humanism" that had been used by the colonial Dutch to subdue the Indonesian independent movement. However, after Indonesia secured its independence, he recanted his previous criticism and thought that liberal humanism fits within the context of an independent state.

3. The arguments and counterarguments of sastra kontekstual reflecting its initial concept and development are collected in Ariel Heryanto's Perdebatan Sastra Kontekstual (1985). 


\section{Works Cited}

Budiman, Arief. "Sastra Kontekstual - Sebuah Penjelasan." Perdebatan Sastra Kontekstual, edited by Ariel Heryanto, CV Rajawali, 1985, pp. 317-22.

Day, Tony, and Keith Foulcher. "Postcolonial Readings of Modern Indonesian Literature: Introductory Remarks." Clearing a Space: Postcolonial Readings of Modern Indonesian Literature, edited by Keith Foulcher and Tony Day, KITLV Press, 2002, pp. 1-17.

Esten, Mursal. Menjelang Teori Dan Kritik Susastra Yang Relevan. Angkasa, 1988.

Fanon, Frantz. "On National Culture." Colonial Discourse and Postcolonial Theory, edited by Patrick Williams and Laura Chrisman, Columbia UP, 1994, pp. 36-52.

Foulcher, Keith. Pujangga Baru. Literature and Nationalism in Indonesia 1933-1942. Flinders University Asian Studies 1980.

--. Social Commitment in Literature and the Arts: The Indonesian "Institute of People's Culture" 1950-1965. Centre of Southeast Asian Studies, Monash University, 1986.

Heryanto, Ariel, editor. Perdebatan Sastra Kontekstual. C.V. Rajawali, 1985.

Kratz, E.Ulrich, editor. Sumber Terpilih Sejarah Sastra Indonesia Abad XX. Kepustakaan Populer Gramedia, 2000.

Mihardja, Achdiat K, editor. Polemik Kebudayaan. Pustaka Jaya, 1977.

Mohamad, Goenawan. "The 'Cultural Manifesto' Affair Revisited: Literature and Politics in Indonesia in the 1960s, a Signatory's View." Monash Asia Institute Press, 2011.

Nordholt, Henk Schulte. "Modernity and Cultural Citizenship in the Netherlands Indies: An Illustrated Hypothesis." Journal of Southeast Asian Studies, vol. 42, no. 3, 2011, pp. 435-457.

Pradopo, Rachmad Djoko. “Kritik Sastra Indonesia Modern.” Dissertation. Universitas Gadjah Mada, 1992.

Said, Edward. The World, the Text, and the Critic. Harvard UP, 1983.

Teeuw, A. Modern Indonesian Literature. Martinus Nijhoff, 1967.

Yuliantri, Rhoma Dwi Aria, and Muhidin M. Dahlan, editors. Lekra Tak Membakar Buku. Merakesumba, 2008. 